\title{
DAMPAK STIMULAN DANA PINJAMAN BERGULIR TERHADAP PERTUMBUHAN EKONOMI PADA PELAKU EKONOMI KREATIF (USAHA MIKRO KECIL DAN MENENGAH, UMKM)
}

\author{
Muhammad Mansur \\ Junaedi \\ Masyhuri Machfudz \\ Nahdhiyatul Kamilah \\ Universitas Islam Malang \\ Email : Masyhuri033@gmail.com
}

\begin{abstract}
The purpose of this study was to provide assistance to creative finance economic actors (MSMEs) and intervention of snacks production management by paying attention to halalan-thoyibah with all the attributes. The research method is participatory action research (PAR). The results of the study showed that (i) stimulant funds given to the target group took place 3 times. The application of the qordhu hasan model transaction formed appropriate technology named $\mathrm{QH}$ $9 K j$, namely qordhu hasan on seven agreements : the number of group members, the number of loans, the number of returns, the number of groups, the amount of return time (for example per week), the amount of savings based on profit obtained, the amount of withdrawal of savings, the number of loans for the next round and the agreement on the amount of money filling voluntarily without being determined and (ii) the intervention of halal production and good by conducting counseling; the result is 89\% satisfaction and carry out with a halal and thoyib production.
\end{abstract}

Keywords: revolving funds, economic growth, creative economic actors, MSMEs.

\section{PENDAHULUAN}

Payung penelitian ini akan dilakukan melalui kebijakan (policy) pemerintah Inpres nomor 6 tahun 2007 tentang pemberdayaan ekonomi kreatif (UMKM) merupakan kesungguhannya dalam upaya pada sektor perdagangan dan perbaikan iklim investasi untuk percepatan pembangunan sektor riil dan pengembangan UMKM.

Pemberdayaan UMKM ini dilakukan penekanaan pada pelaku ekonomi kreatif khususnya pada pedagang-pedagang makanan dan/atau penjual 'jajanan anak-2' di sekolah tingkat dasar dan menengah, karena hasil survei awal mangkalnya mereka adalah pada sekolah-sekolah di kampus yang ada di Malang Raya ini. 
Atas dasar kenyataan di atas, maka akselerasi pembangunan sektor riil dan pengembangan UMKM tersebut, tidak akan mengalami kesulitan dalam aplikasinya. Untuk itulah menarik dilakukan kajian yang mendalam sebagai salah satu bentuk responsi (action) guna mendapatkan bentuk atau model yang ideal pada seputaran UMKM, sebab dari beberapa program yang ada sampai sekarang ini masih segar dalam ingatan kita bahwa ada lima program pokok pemberdayaan koperasi dan UMKM, yaitu: terciptaan kondusif, pengembangan sistem pendukung usaha, program pengembangan kewirausahaan dan keunggulan kompetitif, pemberdayaan usaha dan program peningkatan kualitas kelembagaan koperasi.

Pada level makro kontribusi KUMK pada pembangunan ekonomi secara umum cukup besar, yaitu dari aspek penyerapan tenaga kerja, menambah dan/atau membuka kesempatan kerja lebih baru, dapat dipakai sebagai media pelatihan dan pendidikan kerja dalam rangka meningkatkan skill para pekerja, mencegah urbanisasi, angin segar pada perekonomian dan/atau usahawan yang baru.

Data statistik menunjukkan bahwa eksistensi potensi pengusaha kecil sangat besar, dimana dari 38,9 juta pengusaha, sebanyak 99,8\% diantaranya adalah pengusaha kecil dan hanya 0,2\% yang merupakan pengusaha menengah dan besar. Hal ini mengidentifikasikan masih besarnya potensi ekonomi rakyat yang perlu diberdayakan dan mempunyai hak penuh atas perekonomian nasional. Atas dasar itulah, maka sangat dibutuhkan revisi-revisi guna menjalankan demokrasi ekonomi dan persaingan sehat.

penelitian ini dapat memberikan sumbangan pemikiran yang dapat dipakai sebagai salah satu dasar dalam pengambil keputusan/kebijakan (policy) agar potensi UMKM dapat dikembangkan secara integratif dan berkelanjutan (sustainable). Harapan kebijakan ini mampu memberikan nuansa baru bagi UMKM secara integratif, diantaranya adalah problematik yang dihadapi UMKM secara krusial yaitu permodalan dapat diatasi baik pada jangka pendek maupun panjangnya. Solusi yang ditawarkan untuk meminimisasi problem modal dalam bentuk ekonomi syariah salah satu yang diimplmentasikan adalah transaksi qordhu hasan, yaitu kebajian yang didahulukan dalam rangka untuk mencitkan rasa nyaman kepada kelompok sasaran. Beberapa indikator kebajikan pada penelitian ini adalah berupa pinjaman tanpa 
bunga, tanpa biaya administrasi, menjunjung tinggi kesepakatan bersama, tepat waktu, tepat janji, dan sebagainya dalam rangka mempertahankan eksistensi usaha mereka.

Atas dasar problem klasik di muka, maka tujuan penelitian ini adalah pendampingan pada pelaku ekonomi kreatif pendanaan dalam bentuk stimulan dana pinjaman bergulir (revolving fund) dan 'intervensi' manajemen produksi pada 'jajanan' anak-anak dengan memperhatikan halalan-thoyibah dengan segala antributnya. Kelompok sasaran yang diteliti adalah pelaku ekonomi kreatif (UMKM).

State of the art dalam bidang yang diteliti adalah mencptakan kenyamanan pada kelompok sasaran, stimulan dana pinjaman bergulir (revolving fund) dengan implementasi pada transaksi ekonomi syariah berupa qordhu hasan, tanpa beban bungan administrasi, dalam pelaksanaannya tanpa 'tempat' dan 'tanpa tenaga kerja'. Tempat ditentukan berdasarkan kesepakan tenaga kerja dilakukan atas dasar tunjukan kelompok, dan sebagianya yang inovasinya cukup variasi dibandingkan dengan lainnya. Khusus pada pengolahan makanan dilakukan 'intenvensi' dengan mengintroduksikan konsep halalantoyibah.

Pergerakan ini berawal dari 'keprihatinan' atas semaraknya jenis makanan yang kurang sehat untuk dikonsumsi. Dalam rangka untuk memenuhi ketahanan dan keamanan pangan, maka dilakukan program aksi dari pendidikan, pelatihan dan pendampingan pada pelaku ekonomi dengan 3 pokok kegiatan (i) pendidikan, pelatihan dan pendampingan pada manajemen olah makanan yang baik dan sehat, (ii) stimulan dana bergulir dan (iii) perlindungan makanan melalui HAKI dan uji halalan thoyibah. Aktivitas pada program ini dilakukan atas dasar kesepakatan (agreement) pada semua pihak sehingga target hasil dari kegiatan ini akan terpenuhi sesuai dengan harapan (expectation).

Inovasi model teknologi tepat guna (TTG) pada penelitian ini sementara waktu (short run) bersifat pendampingan dalam rangka untuk mempersiapkan para mental pelaku ekonomi kreatif saat mengalami perubahan-peruabahan waktu yang begitu cepat. Pada jangka panjangnya (long run) diharapkan dalam wkatu yang tepat mereka bersifat mandiri guna mengakses kesempatan-kesempatan yang digulirkan oleh pemerintah berupa permodalan kalangan usaha mikro kecil dan menengah (UMKM) di berbagai pelosok Tanah Air. Kesepakatan 
tersebut tertuang dalan perjanjian kerja sama antara LPDB-KUMKM (Lembaga Pengelola Dana Bergulir Koperasi Usaha Mikro, Kecil dan Menengah) dengan Asosiasi Bank Syariah Indonesia (Asbisindo) guna ikut serta dalam mengembangkan perekonomian daerah khususnya dan kemandirian bangsa pada umumnya.

Pola yang dikembangkan adalah keterbukaan dengan tingkat seleksi secara bersama dan fihak LPDB-KUMKM tetap berhak untuk melakukan seleksi terhadap BPR Syariah calon penerima dana bergulir yang telah direkomendasikan oleh induk organisasinya, yaitu Asbisindo. Dana yang disediakan cukup tinggi sebesar Rp.2,650 triliun untuk tahun 2018 atau terjadi kenaikan 37,57\% dibanding tahun lalu yang sebesar Rp1,926 triliun. LPDB-KUMKM telah menyalurkan pinjaman atau pembiayaan sebesar Rp.4,3 triliun yang disalurkan kepada 2.903 mitra di seluruh Indonesia dengan bung 7\% per tahun.

Dasar teori yang dipakai dalam menjalankan program ini dengan model ekonomi syariah yaitu qardh adalah memberikan (menghutangkan) harta kepada orang lain tanpa mengharapkan imbalan, untuk dikembalikan dengan pengganti yang sama dan dapat ditagih atau diminta kembali kapan saja penghutang menghendaki. Akad qardh ini diperbolehkan dengan tujuan meringankan (menolong) beban orang lain. Qardh ada empat muqridh (pemberi hutang), muqtaridh (orang yang berhutang), muqtaradh/ma'qud 'alaih (barang yang dihutang) dan shighat 'Ijâb qabul (ucapan serah terima).

Syarat muqridh (pemberi hutang), harus memenuhi kriteria (i) ahliyat at-tabarru' (layak bersosial) adalah orang yang mempunyai hak atau kecakapan dalam menggunakan hartanya secara mutlak menurut pandangan syariat dan (ii) ikhtiyâr (tanpa ada paksaan), yakni muqridh (pihak pemberi hutang) di dalam memberikan hutangan, harus berdasarkan kehendaknya sendiri, tidak ada tekanan dari pihak lain atau intervensi dari pihak ketiga.

Syarat Muqtaridh (pihak yang berhutang), harus merupakan orang yang ahliyah mu'âmalah, yaitu sudah baligh, berakal waras, dan tidak mahjur (bukan orang yang oleh syariat tidak diperkenankan mengatur sendiri hartanya karena faktor-faktor tertentu). Oleh karena itu, jika anak kecil atau orang gila berhutang, maka akad hutang tersebut tidak sah, karena tidak memenuhi syarat. 
Syarat Ma'qud 'Alaih (barang yang dihutang), harus merupakan sesuatu yang bisa diakad salam. Segala sesuatu yang sah diakad salam, juga sah dihutangkan, begitu juga sebaliknya.

\section{METODE}

Mekanisme penelitian, melalui beberapa tahap, yaitu mobilisasi tenaga ahli, (ii) singkronisasi pelaksanaan rencana program, (iii) kegiatan pengumpulan data dan informasi dan (iv) kompilasi data sebagai dasar untuk melakukan program.

Unit analisis untuk action ini, dilakukan dengan pendekatan participatory rapid appraisal dengan banyak tahap, dengan melihat (i) kemampuan dalam aspek manajerial, meliputi: perencanaan, administrasi usaha, pemasaran dan penjualan, manajemen keuangan dan belanja, (ii) peningkatan kemampuan teknik produksi, meliputi: peningkatan inovasi produk, peningkatan produktivitas dan efisiensi, dan pengurangan jumlah produk yang rusak dan (iii) perbaikan struktur modal, meliputi: peningkatan kualitas kemandirian modal kerja, penambahan aset dan teknologi produksi, peningkatan jumlah tabungan, dan peningktan jumlah pekerja serta pemasaran dan jaringan.

Metode analisis dengan menggunakan metode yang dikemukakan oleh O'Brien (2001) dalam Machfudz dan Sujono (2012), secara berurutan: (i) perencanaan (plan) dengan memperhatikan kondisi riil kelompok sasaran (pelaku ekonomi kreatif); (ii) tindakan (action). Setelah proses perencanaan dilakukan, kelompok sasaran (pelaku ekonomi kreatif) mengimplementasikan rencana yang telah dibuat tersebut dengan dibantu dan difasilitatori oleh peneliti; (iii) pengamatan (observe). Pengamatan dilakukan untuk memperhatikan dan menganalisis keberhasilan, kelemahan, dan kekurangan strategi dan metode yang digunakan dalam menyelesaikan problematika yang terjadi di kelompok sasaran (pelaku ekonomi kreatif) produsen dan (iv) refleksi (reflect). Usaha-usaha yang telah dilakukan dalam memecahkan problematika kelompok sasaran (pelaku ekonomi kreatif) tersebut direfleksikan dan dievaluasi, baik kekurangan, kelemahan, dan keberhasilan strategi dan metode dalam memecahkan problematika masyarakat tersebut. Refleksi dan evaluasi ini berujung kepada perencanaan (plan) seperti pada poin pertama untuk menuntaskan problematika kelompok sasaran (pelaku ekonomi kreatif). 
Kemafaatan riil lainnya antara lain: (i) kemandirian kelompok sasaran akan terwujud dan mandiri pada saat peneliti ini (program) telah 'melepas' mereka pasca program ini selesai, (ii) kemitraan terbangun didalamnya dan (iii) kutungan adanya tambahan pendapatan (income) melalui stimulasi dana usaha tambahan.

\section{HASIL DAN PEMBAHASAN}

Temuan hasil penelitian pada kelompok sasaran adalah (i) tidak ada tempat 'sekretariat' pada ketua kelompok, (ii) tidak ada karyawan pengumpulan/pembayaran' uang di rumah sekretariat disetor ke penyandang, (iii) tidak ada bunga, apalagi denda, (iv) memunculkan kenyaman nasabah untuk berdagang, (v) adanya harapan dan semangat yang luar biasa karena selesai/lunas hutang ada uang tabungan yang dibagikan, (vi) memunculkan tanggungjawab bersama atas kelancaran dalam memenuhi kewajiban angsuran, (vii) tali persaudaraan (silaturrahim) terjalin setiap pekan/meng-ansur dan/atau setiap penciaran tahap/putaran berikutnya dan (viii) 'rasa empati' terhadap orang yang menghutangi dengan 'mengisi kotak' atas dasar suka dan jika mendapatkan laba dari dagangannya dengan moto yang dikembangkan optimalisasai visi-misi: 'jangan mengisi iuran jika terpaksa, isilah iuran dengan senang hati'.

Tabel 1: Rekapitulasi Dana Bergulir Putaran I dan Tabungan

\begin{tabular}{|c|l|c|c|c|}
\hline NO. & \multicolumn{1}{|c|}{ NAMA } & ANGSURAN & TABUNGAN & JUMLAH \\
\hline 1 & Ramelah & 500 & 100 & 600 \\
\hline 2 & Sundari-1 & 500 & 100 & 600 \\
\hline 3 & Sundari-2 & 500 & 100 & 600 \\
\hline 4 & Noer & 500 & 100 & 600 \\
\hline 5 & Rasi Miskanah & 500 & 100 & 600 \\
\hline 6 & Abidah & 500 & 100 & 600 \\
\hline 7 & Ashab & 500 & 100 & 600 \\
\hline 8 & Uziek & 500 & 100 & 600 \\
\hline 9 & Kunaini & 500 & 50 & 550 \\
\hline 10 & Tarmuji & 500 & 50 & 550 \\
\hline 11 & Pak Dhe & 500 & 50 & 550 \\
\hline 12 & Har-1 & 500 & 50 & 550 \\
\hline 13 & Suci Har-2 & 500 & 50 & 550 \\
\hline
\end{tabular}




\begin{tabular}{|l|c|c|c|c|}
\hline & Jumlah & 6.500 & 1.050 & \\
\hline
\end{tabular}

Sumber: Hasil Eksperimen Putaran I pada Kelompok sasaran (2018)

Prestasi dari angsuran anggota ditunjukkan pada Tabel 1. Dari sejumlah 13 orang pelaku ekonomi kreatif. Tabungan yang mereka lakukan pada putaran I sebesar Rp.100.000,-/10 minggu sebanyak 8 orang (61,54\%) dan Rp.50.000,- sebanyak 5 orang (38,46\%). Dengan demikian pertumbuhan ekonomi dengan indikator sebesar 16,15\%, indikator pertumbuhan ekonomi ini melalui tabungan yang mereka lakukan berdasarkan keuntungan yang mereka peroleh saat melakukan bisnisnya.

Tabel 2: Rekapitalasui Dana Bergulir Putaran II beserta Tabungan

\begin{tabular}{|c|l|c|c|c|}
\hline NO & NAMA & ANGSURAN & TABUNGAN & JUMLAH \\
\hline 1 & Ramelah & 500 & 200 & 700 \\
\hline 2 & Sundari-1 & 500 & 250 & 750 \\
\hline 3 & Sundari-2 & 500 & 250 & 750 \\
\hline 4 & Noer & 500 & 200 & 700 \\
\hline 5 & Rosi Miskanah & 500 & 200 & 700 \\
\hline 6 & Abidah & 500 & 200 & 700 \\
\hline 7 & Ashab & 500 & 200 & 700 \\
\hline 8 & Uziek & 500 & 200 & 700 \\
\hline 9 & Kunaini & 500 & 100 & 600 \\
\hline 10 & Tarmuji & 500 & 100 & 600 \\
\hline 11 & Pak Dhe & 500 & 100 & 600 \\
\hline 12 & Har-1 & 500 & 100 & 600 \\
\hline 13 & Suci Har-2 & 500 & 100 & 600 \\
\hline \multicolumn{2}{|}{ Jumlah } & 6.500 & 2.200 & \\
\hline
\end{tabular}

Sumber: Hasil Eksperimen Putaran II pada Kelompok sasaran (2018) 


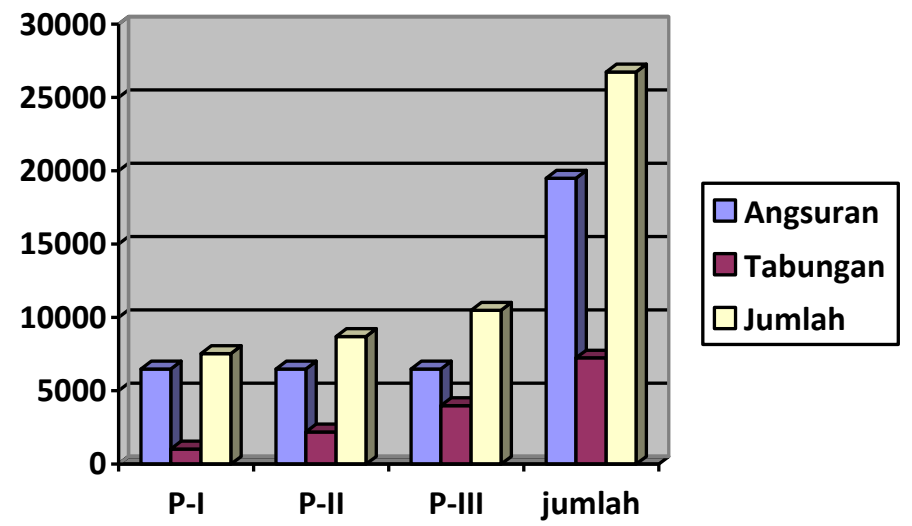

\section{Keterangan:}

- P-I II \& III=putaran I, II III.

- Tabungan menunjukkan kenaikan beriringan dari putaran I, II dan putaran III

Pada Tabel 2. prestasi pada hasil putaran II, angsuran yang dilakukan anggota sebesar Rp.100.000,-/10 minggu sebanyak 5 orang $(38,46 \%)$ dan sebesar Rp.200.000,- sebanyak 6 orang (46,15\%) dana sebesar Rp.250.000,- sebanyak 2 orang (15,39\%). Dengan demikian pertumbuhan ekonomi dengan indikator sebesar 61,54\%, terjadi kenaikan yang cukup significan menjadi $61,39 \%$ dua kali lipat dari putaran I.

Selanjutnya untuk melihat data rekapitulasi pada putaran III, dapat dilihat sebagaimana pada Tabel.3. Tabel tersebut menunjukkan terdapat empat variasi besarnya jumlah tabungan yang mereka lakukan, yakni sebesar Rp.100.000,- dilakukan 5 orang (38,46\%), tabungan sebesar Rp.300.000,- sebanyak 5 orang (38,46\%), tabungan sebesar Rp.500.000 sebanyak 1 orang $(7,69 \%)$ dan terakhir tabungan sebesar Rp.750.000,- sebanyak 2 orang (15,39\%) (Tabel 3). 
Implikasi dari stimulan dana pinjaman bergilir terhadap pertumbuhan ekonomi adalah positif. Indikator pertumbuhan ekonomi dalam penelitian ini dilihat dari aspek tabungan (saving), dengan demikian dapat dikatakan bahwa tarnsaksi dalam bentuk kebajikan (qordhu hasan) ini sebagai salah satu alternatif dalam meminimisasi problem klasik yang dialami oleh UMKM. Sejak dulu sebelum tahun milinium perhatian pemerintah terhadap ekonomi kretaif cukup tinggi dengan mewajibkan penyaluran dana 20 prosen tetapi kesinambungan dalam realita tidak nampak (Maryanto dan Susilo, 1996).

Tabel 3: Rekapitalasi Dana Bergulir Putaran III dan Tabungan

\begin{tabular}{|r|l|c|c|c|}
\hline NO. & NAMA & ANGSURAN & TABUNGAN & JUMLAH \\
\hline 1 & Ramelah & 500 & 300 & 800 \\
\hline 2 & Sundari-1 & 500 & 750 & 1250 \\
\hline 3 & Sundari-2 & 500 & 750 & 1250 \\
\hline 4 & Noer & 500 & 500 & 1000 \\
\hline 5 & Rosi Miskanah & 500 & 300 & 800 \\
\hline 6 & Abidah & 500 & 300 & 800 \\
\hline 7 & Ashab & 500 & 300 & 800 \\
\hline 8 & Uziek & 500 & 300 & 800 \\
\hline 9 & Kunaini & 500 & 100 & 600 \\
\hline 10 & Tarmuji & 500 & 100 & 600 \\
\hline 11 & Pak Dhe & 500 & 100 & 600 \\
\hline 12 & Har-1 & 500 & 100 & 600 \\
\hline 13 & Suci Har-2 & 500 & 100 & 600 \\
\hline
\end{tabular}

Meskipun demikian UMKM masih eksis dan semakin kokoh melalui aplikasi dari transaksi model qordhu hasan yang terbentuk teknologi tepat guna yang diberi nama $\mathrm{QH}-9 \mathrm{Kj}$, yakni qordhu hasan pada tujuh kesepakatan; kesepakatan jumlah anggota kelompok, jumlah pinjaman, jumlah pengembalian, jumlah kelompok, jumlah waktu pengembalian (misalkan per pekan), jumlah tabungan berdasarkan laba yang diperoleh, jumlah penarikan tabungan, jumlah pinjaman untuk putaran berikutnya dan kesepakatan jumlah mengisi uang suka rela TANPA DITENTUKAN dengan visi-misi 'jangan isi iuran jika terpaksa, isilah iuran dengan lapang dada'. 
Tingkat ketenangan nasabah pada aplikasi transaksi ini cukup tinggi 89\% mereka mengatakan bahwa model yang menjunjung tinggi kesepakatan ini secara spsikologis memunculkan semangat dalam berbisnis. Sementara waktu aplikasi perbankan dalam bentuk musyarakah dalam bentuk ventura oleh lembaga keuangan khusus yang diperbolehkan melakukan invenstasi dalam kepemilikan perusahaan, namun ini masih minim karena faktor internal bank, nasabah dan regulasi pemerintah (Misbah, 2007 p.169).

Iinovasi dalam penelitian ini adalah akan dimunculkan pada penelitian-penelitian berikutnya guna mengisi visi-misi untuk melihat pertumbuhan ekonomi secara keseluruhan, disamping akan dilakukan ekspansi pada kelompok sasaran. Inovasi yang dimaksudakan dalam riset yang akan datang, ini didasarkan pendapat dari Wissema (forthcoming) dalam Indarti (2007, p.59) inovasi adalah 'perkenalan yang sukses akan sesuatu yang baru; sukses ditunjukkan dengan penerimaan pasaratau pengguna lain'. Hal ini mengindikasikan bahwa inovasi bukan hanya proses ilmiah atau teknis saja, tetapi juga proses komersial, memasarkan produk baru di pasar.

Indikasi-indikasi yang muncul pada penelitian ini adalah (i) 'pasar' yang merupakan kelompok sasaran menerima pola yang ditawarakan dan disepakati, (ii) relevan dengan ajaran Ekonomi Islam; 'meminjamkan' uang tanpa dibebani syarat merupakan perilaku kebajikan, (iii) dihipotesiskan dengan 'iuran', maka akan kelihatan korelasi yang positif antara kebajikan dan empati (yang diidikasikan dengan 'iuran' suka rela) dan (iv) hipotesis lanjutan berupa responsi kelompok sasaran pada model QH-9Kj secara positif. Dari dua hipotesis ini akan diapkai sebagai 'bahan baku' dalam melaksanakan penelitian lanjutan sebagi pijakan roadmap riset tindak lanjut.

Terdapatnya bukti data di muka tentang laju pertumbuhan ekonomi dari model yang dikembangkan dalam penelitian ini sebagai bekal keyakinan yang mendalam untuk menggembangkan lebih jauh sehingga alternatif jalan menghindari adanya praktek bunga uang dapat diminimisasi. Lebih-lebih dengan perubahan waktu yang begitu cepat dari hari ke hari, pekan, bulan hingga masa berubah dari berbagai dimensi.

Akan menjadikan salah satu alternatif pilihan model yang dikembangkan pada penelitian ini baik pada masa kini, maupun masa 
ekonomi masyarakat Asia maupun Eropa (global). Karena itulah globalisasi masa yang secara alami akan terjadi, kekwatiran yang berlebihan menjadikan kemubadhiran energi yang keluar, kreatifitas dari pelaku-pelaku ekonomi level UMKM menjadikan fondasi yang amat kuat dari berbagai perubahan waktu.

\section{KESIMPULAN}

Atas dasar pembahasan hasil penelitian di muka, maka disimpulakn bahwa (i) terjadi stimulan dana diberikan kepada kelompok sasaran hingga penelitian ini berlangsung sudah 3 kali putaran. Setiap putaran memerlukan waktu 10 minggu untuk melunasi dana pinjaman tanpa dibebani bunga dan biaya apapun, bersamaan dengan pengembalian semua anggota kelompok sasaran wajib menabung semampunya yang sebagai satu-satu sebagai indikator pertumbuhan ekonomi dalam riset ini. Putaran I, II dan III pertumbuhan ekonomi berturut-tururt 16,15\%, 33,85\% dan 61,54\% dari total dana pinjaman. Disamping itu, aplikasi dari transaksi model qordhu hasan ini terbentuk teknologi tepat guna yang diberi nama $\mathrm{QH}-9 \mathrm{Kj}$, yakni qordhu hasan pada tujuh kesepakatan jumlah anggota kelompok, jumlah pinjaman, jumlah pengembalian, jumlah kelompok, jumlah waktu pengembalian (misalkan per pekan), jumlah tabungan berdasarkan laba yang diperoleh, jumlah penarikan tabungan, jumlah pinjaman untuk putaran berikutnya dan esepakatan jumlah mengisi uang suka rela tanpa ditentukna dan (ii) 'intervensi' produksi halal dan baik dengan melakukan penyuluhan; yang hasilnya 89\% mengalami kepuasan dan melaksanakan apa yang telah disekati bersama untuk melakukan pengelolaan produksi yang halal dan baik.

Dengan demikirian rekomendasi yang disarankan adalah perlu penelitian lanjutan dengan memerlukan analisis yang mendalam dan aksi secara optimal dengan visi-misi: 'jangan isi iuran jika terpaksa, isilah iuran dengan lapang dada'. Dihipotesiskan dengan 'iuran', maka akan kelihatan korelasi yang positif antara kebajikan dan empati (yang diidikasikan dengan 'iuran' suka rela). Demikian juga hipotesis lanjutan berupa responsi kelompok sasaran pada model QH-9Kj secara positif. Dari dua hipotesis ini akan diapkai sebagai 'bahan baku' dalam melaksanakan penelitian lanjutan sebagi pijakan roadmap riset tindak lanjut. 


\section{DAFTAR PUSTAKA}

--------, (2008). Workshop Implementasi Inpres No.6/2007 Tentang Percepatan Pembangunan Sektor Riil dan Pengembangan UMKM . Malang.

Maryatmo dan Sri Susilo. (1996). Dari Masalah Usaha Kecil sama Masalah Ekonomi Makro. Yogyakarta: Andi Offeset. ISBN: 979-8109-70-8, hal 16.

Misbahul, M. (2007). Ajaran-Ajaran Ekonomi Rasulullah. Malang: UIN Maliki Press. ISBN:979-24-2955-7.Hhal.1169.

Mansur, Muh., (2013). Pemberdayaan Masyarakat Tani Melalui Kemitraan dengan Koperasi Susu Sapi Perah 'Setia Kawan' (KSPSK) Di Kecamatan Tutur Nongkojajar Pasuruan. Jawa Timur. Malang: Jurnal Ekonomi dan Bisnis. Iqtishoduna. ISSN: 1829-524X. (hal.220229).

(2014). Penmberdayaan Masyarakat Tani Melalui Kemitraan dengan Koperasi Susu Sapi Perah 'Setia Kawan' (KSPSK) Di Kecamatan Tutur Nongkojajar Pasuruan. Jawa Timur. Nomor Kontrak: 061/SP2H/KM7/2014. 13 April 2014 (Laporan penelitian Tahun II).

Masyhuri, M. (2010). Pengembangan Model UMKM yang Integratif dari Aspek Kebijakan Pemerintah Guna Mendukung Manajer yang Handal. ISBN: 978-602-958-290-1. Hal. 1-17. 1 Juni 2010.

-------- dan MN. Sujoni. (2012). Pemberdayaan Pedagang Kecil (mlijo) melalui Aliansi Koperasi Syirkah 'Sunan Kalijaga dengan BMT Syariah. Laporan Pengabdian: Ib-M.

Nurul, I. (2007). Entreprenership dan Usaha Kecil Menengah di Indonesia. Yogyakarta: Ardana Media. ISBN: 979-1118-30-7.

http://www.neraca.co.id/article/41340/LPDBKUMKM-dan-BPR-syariahJalin-Kerja-Sama 